\title{
Perception of Turks and Common Ancestor in Kazakh Genealogy*
}

\section{Seyfullah Yıldınm** \\ Mehmet Topay $^{* * *}$}

\begin{abstract}
The chart showing all the members of the genealogy, starting from the farthest ancestor of a person or family to him, is defined as the genealogy. These genealogies, called "Şejire" (шежipe) in Kazakh Turkish, are an important genre in Kazakh oral literature, and have long been sung by representatives of oral utterance tradition such as aqyn and zhyrau in oral tradition and delivered to the present day, and today they have been substantially in written form. Genealogies, although have undergone major changes when being verbally transmitted from generation to generation, are one of the most important sources of oral history. So much so that we learn many historical personalities and events, Oghuz Khan for the beginning, which is of great importance in Turkish history, from the so-called "Oghuznāma". Kazakh genealogy is seen to be particularly influenced by the works of Shajara-i Taräkima (Genealogy of the Turkmens) by Abu al-Ghazi Bahadur Khan and Jāmi al-tawārìkh (Compendium of Chronicles) by Rashīd al-Dīn Hamadanī. In this article, we will focus on the genealogy tradition of Kazakh Turks and the perception of Turks in genealogies linking the Kazakhs to the Turkish origin and the individuals considered common among Turks will be tried to be pointed out.
\end{abstract}

\section{Keywords}

Kazakh Turks, the tradition of genealogy in Kazakhs, Turkish Perception, Common Ancestor, Oghuz Khan.

\footnotetext{
- Date of Arrival: 07 December 2020 - Date of Acceptance: 26 April 2021

You can refer to this article as follows:

Yildırım, Seyfullah, and Mehmet Topay. "Perception of Turks and Common Ancestor in Kazakh Genealogy.” bilig, no. 100, 2022, pp. 37-58.

" Ass. Prof. Dr. Ankara Yildirim Beyazit University, Faculty of Humanities and Social Sciences, Department of Turkish Language and Literature - Ankara / Turkey

ORCID ID: 0000-0002-4345-6524

s.yildirim@ybu.edu.tr; seyfiyildirim@gmail.com

"'Lecturer, Ankara Yildirim Beyazit University, Rectorate / DILMER - Ankara / Turkey

ORCID ID: 0000-0003-4191-7838

mtopay@ybu.edu.tr
} 


\section{Introduction}

Mankind began to think about the world in which he lived since his creation and asked himself questions pertaining the creation of the world he lives in with all its elements and himself. His sacred answers to questions about himself and the world have revealed myths. In order not to forget about the adventure he had throughout the history, in the later periods of his existence human beings on the world began to record of this historical adventure of his own bloodline orally or in writing in an attempt to both recall and transfer experience.

In the historical process, as in other communities on earth, Turkish communities and representatives of this bloodline have always considered genealogies important and these were tried to be preserved in writing or orally. To have the knowledge of genealogy also means to know and protect its place in the history scene. Therefore, the tradition of genealogy, which we can call history or oral history, is in a way the cultural history of the communities as well as the political history. Exogamy is widespread among Turkish communities, especially in Kazakh and Kyrgyz Turks, and hence disclosure of belonging and identity through lineage and the knowledge of the bloodline is of great importance for these reasons. Therefore, the transfer of genealogy to younger generations and the knowledge of ancestors became a compulsory cultural knowledge. Therefore, the saying of "a Kazakh/Kyrgyz, who does not know his seven ancestors, is not a real Kazakh/Kyrgyz" among the Kazakhs and Kyrgyz remains valid and strong today (Çeribaş, Kırgzz Şecerecilik 63). As a similar tradition in Turkmenistan Turks, it is considered important to know the seven ancestors, and even some laws have been passed in the post-independence period (Illiyev $\mathrm{x}$ ). Also, in the Kazakh and Kyrgyz today, it is considered forbidden to marry young people with kinship ties among them up to seven ancestors (Arvas 104; Yeşil, Türk Dünyasında 165) has made it kind of mandatory to know genealogy. The obligatory acceptance of knowing the seven ancestors and genealogy is based on the belief that they can benefit from the spirit of ancestors in shamanism (Yeşildal 53).

The tradition of genealogy was preserved verbally as a result of the way of life. The tradition of oral expression ensures the continuity and development of the cultural elements necessary for the continuation of 
human generation (Yeşil, Türk Sözlü 14). After these communities with oral tradition were represented by a specific management unit through an institutional structure, transferring cultural elements belonging to that society to written form to a certain extent started. Different literary and narrative types have emerged about the forms of expression of cultural elements both verbally and in writing. These types are genealogy, geneepistles, genealogical tree, etc. In addition, some of the works described by genealogy are not only limited to these, but also some epics have this feature when viewed in broader sense. Oghuz Khan's Islamic period variants and narratives classified under the name of historical epic in the tradition of Turkish World epic are also included in this group. Because epics are also heroic together with social values, historical events, ideal types, love of homeland, etc. they were considered useful in terms of ensuring social coexistence intended to be transferred to the next generations (Kayabaşı 11). Therefore, the introduction of historical heroes in epics can be regarded as a clear indication that he, in a way, serves his genealogical consciousness.

Şecere (genealogy) is described as coming from the root of Arabic word şücur (tree) with a meaning of "The schematic drawing of the most distant ancestors in the form of a tree showing the root of a family by imaging fathers and their children in the position of a trunk and branches" in the Islamic Encyclopedia (Bozkurt 403; Türk Dünyası Edebiyat Kavramlar ve Terimleri Ansiklopedik Sözlüğ̈ 381). In Turkish, the same concept is expressed with the word soyağacı and in Turkish dictionary it is described as a chart in which the genealogy and the descendants of ancestors are written (2210). The concept of şecere passed from Arabic to Turkish, with some phonetic changes as şejire in Kazakh Turkish, şəcərə in Azeri Turkish, şəcərə in Bashkir Turkish, sancıra in Kyrgyz Turkish, şəcərə in Tatar Turkish, şäcärä in Uzbek Turkish, şecere in Turkmen Turkish, şäcirä in Uyghur Turkish (Türk Dünyası Edebiyat Kavramları ve Terimleri Ansiklopedik Sözlüğ̈̈ 381). In the Qazaq Ädebi Tilinin Sözdigi (321) we see the following definitions of the terms "şecire" and "şecereci" as in article "Şejire" (шежіре) as the case in which historical events are written and a branch of history of science indicating the roots and the spread of a nation; and in article "Şejireşi" (шежіреші) as a person who verbally transfers the history of the people, the way of living from generation to generation. Genealogies, apart from the task of a chart showing the family tree, have become a literary genre with 
the name "gene-epistles" by including the epic stories that existed among the people over time. It is possible to consider genealogies in two categories when analysing in terms of the Turkish cultural circle with works such as Oghuznāma, Cengiznāma, Shibanīnāma (where näma means epistle), which based the genealogy of Turks on Noah's son Jafes, mentioning the cult line in certain cult circles (Karasoy et al. 7, 18).

Nations have written works of genealogy based on the idea of how old they have existed in the historical process. These works sometimes begin with the common ancestor of the people as Adam, and sometimes Noah as the second ancestor, and sometimes the communities in which they lived together in the past in the union of origin and culture. The works that mention the family tree of Turks or Turkish communities are generally in this manner and descendants of Turks are shown to be Jafes, son of Noah. In later periods, Turkish communities referred to by different names also had their own governments and administrative structures in time and began to write works about their own bloodline. The work of the 16th century century Mejmüa altawärikh, which started with the Islamic Prophet and also mentioned religious, historical and cultural heroes such as the Twelve Imams, Genghis Khan, Emir Timur $^{1}$, Toktamish Khan and Manas, is one of the distinguished examples of genealogies created in Turkish world in the Uzbek-Kyrgyz cultural circle (Çeribaş, Mecmû̉üt-Tevârîh 12; Temur 225-226).

According to Şäkärim Qudayberdiulı (7), there is no genealogy from Adam to present without interruption. The Torah is the source of all genealogies from Adam to Noah. The sequel is usually created with hearsay information. As well as the share of reality, many feigned genealogies that tell the story of coming from a noble or scholars' family, binding those to the descendants of khans were formed. This is also observed in some Kazakh genealogies.

In the 15th century, Janibek Sultan and Kerei Sultan did not accept the domination of the Uzbek Khan Abu al-Hayr and established the Kazakh khanate with their respective tribes and different Turkish tribes within the borders of the khanate were called "Kazakh" (Kesici 17). Among Kazakh Turks who are the important representatives of horseback nomadic culture, soy and kinship ties are given much importance. According to social rules, each individual is obliged to learn at least 7 ancestors $^{2}$ in childhood. With phratry beys and wise old men this number goes up to 15-20 ancestors. The 
master in genealogy called "Şejireş»" (шежірешi, chronicler) can count up to 77 ancestors and transfer the important events that happened during the period of these ancestors. Only children who have lost their parents at a very young age are excluded from this social obligation with the saying Jeti atasin bilmegen jetimdiktiñ saldar (not knowing the seven ancestors is an indicator of orphanage) (Mıñjan 38).

Shajara-i Taräkima (Genealogy of the Turkmens) by Abu al-Ghazi Bahadur Khan, considered as a sequel to the work of Jämi 'al-tawärìkh (Compendium of Chronicles) by Mongolian historian Rashīd al-Dīn Hamadanī, was acknowledged by all the Turkish communities and led to the formation of a genre under the name of Oghuznāmas (Çeribaş Kirgız Şecerecilik 62). Oghuznāmas held an important place to the descendants of Kazakh Turks, which is important in the tradition of Kazakh genealogy, by placing their genealogies to Noah and his son, Jafes, and in the line of forefathers, to the Turkic Ata. With the words of Kazakh historian Maqsat Alpısbesulı, "genealogy shows that it is not possible to evaluate Kazakh history beyond the general Turkish history until the end of the Middle Ages" (Alpısbesul1 8). Therefore, in the tradition of genealogy among the Kazakhs, this approach in general is observed.

As a result of the nationalities policy laid in the Tsarist period, in the Soviet era Kazakh and other Turkic phratries were made to be removed from Turkic and Islamic circle in which they had belonged to. As a natural result of this, certain changes in the names of the origin and natural countries were observed as in the name of the Turkestan was replaced by the name of Central Asia, the Kazakh by the Kyrgyz, and the Kyrgyz by the Black Kyrgyz. The effort to create an artificial history and origin with very few written history traditions to communities living a nomadic life such as Kazakh and Kyrgyz reached its peak during the Soviet Union (Çeribaş, Manas Destaninin 207-208). Ultimately, it is seen that these efforts to show the Turkish phratries as separate nations proved to be successful. As a result of the policies applied in this period, the idea of being a detached nation seen in the Turkish descendent communities in the Soviet Union repercussed in the Kazakhs. The effects of this situation showed themselves in Kazakh genealogy, regardless of the tradition of Oghuznāma, in that genealogies that narrated Kazakhs and Kazakh phratries as a separate nation 
from the Turks were also formed. This study focuses on the genealogies that connect Kazakhs to the Turkic lineage and aims to lay out the perception of the Turkic image and narrative of the common figures among the Turks in these mentioned genealogies.

\section{Kazakh Genealogies}

Folklore products of Kazakh Turks from past to present within the scope of Mädeni Mura (Cultural Heritage) project, which was created with the incentive of the founding President of Kazakhstan Nursultan Nazarbayev, were collected in 100 volumes of Babalar Sözi. The 32nd, 81st and 82nd volumes of the work are dedicated to Kazakh genealogies. These three volumes consist of 47 genealogies. There are also separate genealogies of people such as Şäkärim Qudayberdiulı, Mäşhur Jusip Köpeyulı (2007). In general, when Kazakh genealogies are examined in general it can be said that these three main views on the lineage of the Kazakhs have come forward: 1 . Those who accept the Kazakhs directly from the Turkish descendants, 2. Those accepting the Kazakhs from the Arab descendants, 3. Those who considered the descendants of a person who went from Central Asia to Arabia and hence with Turkish/ Kazakh origin but Arabian tradition. In our study, we examine six genealogies included in the series $(32,81$ st and 82nd volumes) from "Babalar Sözi" that stand out among 47 genealogies considering Kazakhs as Turkish, and evaluate the Turkish perception and common ancestor subject.

\section{General Genealogy of Kazakhs}

The genealogy known as Qazaqtıñ Jalpı Şejiresi is a genealogy found verbally and in writing among the Kazakhs in the Altai region of East Turkestan. It is a genealogy in the form of verse and compiled and prepared for publication from Kitapbay Aqmollaulı (Babalar Sözi 32/ 376).

Tarihtı zerttegen jan jönin tabar, The person who examines history finds the truth.

Älemnen on segiz miñ bolsa habar. News coming from eighteen thousand universes.

(Babalar Sözi 32/ 9).

It suggests that starting with genealogy in this way makes the reader or listener to feel from the very beginning that what is told is a historical reality. 
In genealogy, the name of Adam is first mentioned, and then passed directly to Noah simply by saying there are many ancestors among them. According to the genealogy, Noah had three sons and three daughters. The names of the male are Ham, Sam and Yapas (Jafes) and the holy books Psalms, the Bible, the Torah and the Quran are shown as the source. The ancestors of the nations on earth are attached to the three sons of Noah. It was narrated that Ham's descendants are Americans, Africans, Indians and Afghans; Sam's descendants are Arabs. Yapas has eight children. One of them is Turk. Turk has four sons: Tütik, Hakal, Barısjar and Ämlaq³ . In the narration; Eljahan, son of Tutik, Baqoy Khan son of Eljahan, Kiyik of Baqoy, Kiyik’s son Alanşı Khan, Alanşı's son, Mońgol (Mongol) and Tatar. Mońgol also has four sons. These are Özhan, Yıldızhan, Közhan and Karahan. ${ }^{4}$ In the genealogy, Oghuz Khan is the son of Karahan and the grandson of Mongol. It is noted that while Oghuz Khan lived and for many years after he died the Turks lived without religion for a long time. Then Buddhism spread among the Turks, and they ultimately adopted the religion of the Prophet Muhammad, Islam.

Although Oghuz Khan was mentioned to be a great khan that lived for many years and whose fame spread to the world, there is no information about Oghuz Khan's wives, his expeditions and the 24 phratries of Oghuz. Oghuz Khan's children's names are Ayhan, Künhan, Juldızhan, Tavhan, Kökhan and Teñizhan and in the genealogy they are narrated according to the characteristics of speech in Kazakh Turkish. However, the generations of Oghuz Khan's lineage were not continued after Bozok and Üçok, and the genealogy continued to be told through Teñizhan. Although in Shajara-i Taräkima, the names of the six sons born of Oghuz Khan's main wives and 23 children of his second wives are mentioned, in this genealogy only the names of Teñizhan's sons are narrated. Teñizhan had two wives. He had four sons from his main wife, Ava, Qanıq, Eljan and Negiz ${ }^{5}$ and 24 sons $^{6}$ from the second wives. Turks are said to come from the descendants of their sons born from Teñizhan's second wife, but which of the 24 sons they come from is not mentioned. This aspect is described in genealogy as follows:

Toqaldan jiyırma tört ul köripti.

Tänir asırap bäri de körkeyipti.
He had twenty-four sons from second wives.

God raised, and they were all beautiful. 
Tarağan qaliñ qavım osılardan, Äygilep bir kindikten sonşa köpti.

Taralgan osılardan qaliñ Türik, Şejire-şejire bolmas aytsa ötirik.
Crowds spread out of them, Spread so many people from the same lineage

Crowds of Turk spread from them, Genealogy wouldn't be a genealogy if told a lie.

(Babalar Sözi 32/ 13).

In the Kazakh genealogy named Qazaqtıñ Jalpı Sejiresi, the family register of the Kazakhs comes from Noah, to Yafes, to Tütik, to Eljahan, to Baqoy, to Kiyik, to Alanşı, to Mongol, to Karahan and to Oghuz Khan respectively. It is said that there are countless generations derived from Oghuz Khan, and the descendants of Turks come from Deniz Khan, son of Oghuz Khan, and the Kazakhs are also included in this lineage. The children of Oghuz Khan's other sons are not in the genealogy. After the common ancestor that went up to the children of Deniz Khan, genealogy continues narrating Kazakhs by stating that they are descendants of Turks and without mentioning any other ancestors and how long it had passed. Among the Turks, phratries who lived freely nomadic life in the steppe, first referred to as "kaçak (fugitive)", then this word was transformed to the word "Kazakh", after which it was noted that those who continued nomadic life with animal husbandry were called "Kazakhs". Turks are said to build cities and engage in agriculture and crafts.

Türkiler otırktı el bolısqan,

Tuvistıq aytqandarı em bolısqan.

Qala bop qaliñ avil ornalasip,

Egin men qolönerge qol qoyzsqan..
Turks have chosen the sedentary life, Relative's word is medicine.

Crowded villages settled and became a city,

They were engaged in agriculture and craft.

Köspendi el jüre bergen Qazaq bolıp, Nomadic people, then called Kazakh, Tartqanı qus pen jutta azap bolıp.

(Babalar Sözi 32/ 17).
Had their punishment in winter and famine. 


\section{Heroic Turk, The First Ancestor of the Kazakhs}

The copy of Qazaqtıñ Tüp Atası-Batır Türik was compiled from a source named Bedelbek Ezhenbekuly from Dörbiljin (Emin) county of Tarbagatay region in 1990. It is also known among the local people as the "Epic of Kazakh History". First of all, the date of the narration and the narrators are unclear. But the source, that is Ezhenbekuly, said, "I heard that this genealogy was written by Şäkärim Qudayberdiulı from my elders, but I do not know for sure" (Babalar Sözi 32/ 376).

Qazaqtın tüp atası batır Türik,

Arapsiñ değen sözdin bäri ötirik.

$\breve{G a k a s ̧ a ~ s a h a b a n i n ̃ ~ u r q ı s i n ̃ ~ d e p, ~}$

Aldă̆an din jamıl冖̆an öñkey jülik.
The first ancestor of the Kazakhs, the heroic Turk,

You're an Arab! What you say is all fabricated.

Claiming you are descendant of sahaba Ukasha,

All those who cheat in the guise of religion are deceitful.

\section{(Babalar Sözi 32/ 59)}

From the first line of genealogy, it is stated that the origin of the Kazakhs is Turkish, and the idea seen in some Kazakh genealogy that Kazakhs are descendants of sahabas (companions) like Ğakaşa/ Ukaşa (Ukasha) and/ or Annas/ Änes, namely descendants of Arab, are opposed with a definite attitude. In the genealogy, Turk is the son of Jafes and the grandson of Noah. In the Kazakh genealogy tradition, there are examples connecting the origin of the Kazakhs to the Arabs. An example is a genealogy called Jazuvğa Şejireni Aldım Qalam (I got the pen to write the Genealogy). In this genealogy Araptan Qazak eli tarald (Kazakh people derived from the Arab), Türikpenmen irgeles aval boldn (Then neighbored a Turkmen village), Er türlü şejireden kördik solay (We have seen so in many genealogies), Birev Ğakaşadan dese, Tağı birev Makkay Annastan der (If one says from Ğakaşa, some other says from Makkay Annas). In many verses like this, the descendants of the Kazakhs are shown as Arab origin and are linked to the sahabas (Babalar Sözi 32/ 103). We can say that this situation was caused by the influence of Islam. However, during the Soviet Union, since then the ban was imposed on all things that were especially religious in the period, this issue was 
discussed in a different way, notably in order to break the relationship to the Turks of Turkey and the Turkic World. This time, in contrast to the example given above, Turkish Turks have been accused of Arabizing. For example, Kyrgyz genealogy and epics narrate about going to Anatolia and talking about the Arabized Turks. In this context, Sagımbay Orozbakov's Manas Epic expresses the Turks who went to Anatolia and hence Arabized, and Turks who went to Tajikistan and became like the Tajiks. This situation is a result of the "They are not Turks anymore, do not look up to them, take care of yourself" propaganda of the Russians to the Turkish phratries who accepted Turkey as a leader. Seeing the reflections in the genealogies as well demonstrates that the propaganda had been effective in the eye of society as well (Çeribaş, Manas Destaninıın 223).

An important issue that should be emphasized in this genealogy is the mention of the real name of the Turk as "Näduvleșe" (Babalar Sözi 32/ 59). According to the genealogy, Näduvleşe is also the one who found the fire. The name Näduvleşe and the discovery of fire recalls one of the legends about the derivation of the Göktürks from the wolves. Legend has it that the ancestors of the Göktürks lived in the north of the Huns. One of their chief's children was born of the wolf and then married the daughters of the summer and winter gods. Then he had four children, and the eldest of them lived in the mountains of Chien-su and Xin. He found the fire because these mountains were very cold and fed the people who lived there. Then they met with the other brothers, and their brothers elected him as leader and gave him the title of Turk. In addition, the special name of the Turk is $\mathrm{Na}$ Tu-liu (Ögel 1/ 27-28). It can be considered that, the cold Chien-su and the Xin mountains in the legend were replaced by the snowy Altai mountains and $\mathrm{Na} \mathrm{Tu}$-liu, which was written in Chinese spelling, was adapted in the form of Näduvleşe to Kazakh. Apart from this, the name "Näduvleşe" is not seen in any other sources we can reach. Only Samat Sipatayulı refers to this term. According to Sıpatayul, the origin of the word is Neduvleş, and the letter "e" at the end was added afterwards. "Näd" is the word for "supreme" that the Kipchaks in Hungary continue to use today. He says that the word "uvleş" means "bird". So, he describes "Näduvleşe" as "Ulukuş (supreme bird)" (5). 
Qarlı Altay qattı suvrq tavda jurip,

Ot jaqqan Näduvleşe tastı urip. Suvqqtan elin söytip saqtağan son,
Lived in the very cold mountain in Snowy Altai

Näduvleşe hit the stone and lit a fire. Upon protecting his people from the cold

Türik dep han kötergen patşa qulip. They named him Turk khan, a king. (Babalar Sözi 32/ 59)

After the mention of Jafes's son named Turk in the genealogy, the other ancestors who were in between were skipped and the genealogy continued to tell about Oghuz Khan. Oghuz was said to be the grandson of the Mogul Khan, but Oghuz's father, wives and children were not mentioned. Oghuz Khan, who lived 340 years before the Prophet conquered all of Asia and then conquered the Greek land, the West and most of the Arab lands, was mentioned that his fame spread throughout the earth as a valiant, wise and fair leader. In this genealogy, Attila, the European Hun Emperor, who is not found in other genealogies, was also described. According to the genealogy, Attila is the son of the Mogul Khan. He completely conquered Asia and Europe. It has been 1350 years since his death. If we accept this correctly, based on the date of Attila's death, we conclude that the genealogy was written in 1803. But the fact that Attila was the son of the Mogul Khan means that he was the father or uncle of Oghuz Khan. This suggests that genealogy is not reliable in the historical source aspect.

Among the Kazakh genealogy examined, Qazaqtin Tüp Atast-Batır Türik includes parts about Suleyman Shah, Ertughrul Ghazi and some other Ottoman sultans and doing so can be stated as the biggest difference that distinguishes this genealogy from others from the point of view of perception of Turks. In other Kazakh genealogies, after a point the connection with Turks was severed, and the genealogy continued in specifics with Kazakhs. In this genealogy, both the ancestors of the Kazakhs in their territory and the Turks who migrated to the west, accepted in the concept of common ancestors for the Kazakhs, and regarded the ancestors of the Anatolian Turks as their ancestors. In genealogy the following is said about this topic: 
U⿺̆丶

Öz bavırın ol Türik osını añ̆gar.

Qorliqta biz qul bolip otirsaq ta,

Köp şıqqan atamızdan arıstandar.

(Babalar Sözi 32/ 63)
Know this saying o' youth,

That Turk is your brother, you realize that.

Although weare servants under persecution

Many of our ancestors have thrived.

Again, this genealogy is in the highest level of highlighting awareness and pride of Turkishness among Kazakh genealogy. This can be understood from the following lines.

Türikten şıqqan talay sayıpqıran, Jer yüzi titiregen Türik dese. (Babalar Sözi 32/ 59)
Many mighty leaders rose from the Turk, The earth trembled when heard Turk.

As can be seen in this genealogy, Turks left Turkestan and arrived in Anatolia, and so it differs in the way it shows common Turkish ancestors and Turkishness consciousness. It is clear that the perception of common culture and belonging continues is indicative that this work was written when assimilation policies were not yet formed or fully settled among the public. This strengthens the idea that genealogy was written at least before the Soviet Union era.

\section{Turkish Tribes and Kazakh Wusuns ${ }^{8}$}

The genealogy named Türik Taypaları jäne Qazaq Üysiñderi was created by Töltay Meñlibayulı from the stories gathered from the common people. This genealogy, which describes the division of the Kazakhs from Adam into zhuzes (horde), is located in Volume 81 of the Babalar Sözi (Babalar Sözi 81/ 371).

Jazuvğa Türik näsili aldım qolga, Now to discuss the Turkish generation, Järdem et, Jaratuvşı, öziñ oñda Help me, o' Creator, watch over me. (Babalar Sözi 81/ 11).

In the continuation of the genealogy of which the first two lines given above, a long prayer and praise ${ }^{9}$ of Allah (j.j.) comes. In the following parts, the next generation of man is based on Adam, and the beginning of history is based on Noah. Noah has three sons: Ham, Sam, and Yafes. From Yafes, two tribes called Asia and Turan were formed. Turk tribe was formed from 
Turan, and two tribes named Turk and Skif (Scythian) from Turk. The Tatars and Mongols were derived from the Turks and it was stated that the Turks were related to the Finns. When it comes to Oghuz Khan, it is said that five phratries named Turkmen, Uzbek, Kumuk, Haye ${ }^{10}$ and Kipchak descended from him. In addition, important historical figures such as Tomris Khan and Mahmoud of Kashgari are mentioned in the genealogy.

In this genealogy, shortcomings are noticeable about specifying the family tree of Turks starting from Adam. The genealogy can be referred as a poetic description of revealing a long history rather than a genealogical tree. But the connection of the Kazakh generation to Turk, the son of Jafes, as seen in Oghuznāmas, is important in terms of our subject matter.

\section{Kazakh Genealogy}

The narrator of the genealogy known as Qazaq Şejiresi, Jaqsilıq Tölepulı was known for his epic and storytelling among the people and was born in the province of Konırat, located within the borders of today's Karakalpakstan. The copy of Babalar Sözi in volume 81 is written in Arabic letters and was taken from J. Aralbayev in 1946 (373).

The genealogy named Qazaq Sejiresi is not an example of genealogy progressing like the others starting from Adam and continuing to Noah, Jafes and Turks. It is worth noting in that it contains the Kazakh variant of the Ergenekon Epic. According to the genealogy, Turks, Tatars, Kazakhs and Sozaks ${ }^{11}$ had always lived together. When the populations and animals of these communities were multiplied, they became incapable of fitting where they were. In the territorial war with the Chinese and the Mongols, they took a great defeat and were banished from the Altai region. After a long journey, the people settled in a place where it did not even see the sun, lived and propagated four centuries away from war, without even seeing the sun rise and set. They called this place Erkinahun (Ergenekon) ${ }^{12}$. Eventually, they got out of there by finding a way out. The people who saw the sky, the moon and the stars feasted for two months. They named this holiday as Kegen-Shagan. Afterwards, they fought again with the Chinese and the Mongols to take back their homeland Altai, but they were defeated again. After this defeat, the Turks, the Tatar and the Kazakhs headed west. Sozaks stayed in Saryarka and separated from the others. After the Turks, 
Tatar and Kazakhs visited many places in the West to keep their homeland together, the Turks fought with the Romans. As a result of long wars, the Turks conquered ${ }^{13}$ Istanbul and settled there. The Kazakhs couldn't find a home in the Crimea, the Caucasus, the Balkans and many other places, and eventually they returned to Saryarka. There is no information about where the Tatars settled in the genealogy.

The Turks are not shown as the ancestors of the Kazakhs in this genealogy. In the episode where there is a variant of the Ergenekon Epic, Turks, Kazakhs, Tatar and Sozak were shown as brother communities to Each other. It is said that Uzbek Khan was the first khan of the Kazakhs, and after his death Turk's son, Alaş ${ }^{14}$ became the Kazakh khan.

Türik hanniñ balası Alaş attı,

Oqığan, tereñ oylı, mağlumattı.
Son of Turkish khan, named Alaş,

He's educated, thoughtful, knowledgeable.

Özbek han ölgennen soñ han boldr, Took throne after Uzbek Khan died, Alaşa dep alıptı "Alaş" attı (Babalar Sözi 81/ 52)
As he is short, had the name "Alaş".

\section{A Brief Summary of Kazakh Genealogy Written as a Poem}

This genealogy of Qazaq Şejiresinin Öleñmen Jazllğan Qısqaşa Mazmundama was written in Arabic letters and the manuscript was taken from Qanen Qorjınulı. Genealogy was first published in volume 81 of the Babalar Sözi (374). This genealogy is not a shortened form of any other genealogy. It is a self-contained short Kazakh genealogy written as a verse.

In the genealogy, the idea that the Kazakhs were of Arab origin was claimed false and the causes and source of this false information were explained. By saying Qazaqqa Arab bolmaq ğajap is, sekildi jer men köktiñ şeqarası (It is interesting to see Kazakhs as Arab descendants, as to see the edge of earth to the sky) it was emphasized that it was impossible that the Kazakhs were of Arab origin (Babalar Sözi 81/ 54). So why is it seen in some genealogies that Kazakhs come from Arab origin? In the genealogy, this issue is clarified. When the Russians took over the Kazakhs, they were ridiculed by saying that the Kazakhs were heathen ${ }^{15}$. They were said to show their genealogies to prove that they were Muslims. But because of the destruction of the archives, 
they could not prove that they were a Muslim community. After that, the Kazakhs sent two people named Qunanbay and Mirq1 on a pilgrimage to Shaykh al-Islām Seyyidzāde. Seyyidzāde wrote a genealogy showing that the Kazakhs came from the descendants of Änes, one of the sahabas of Prophet Muhammad, and said "If anyone asks, you show this." This genealogy, which Kazakhs had thereafter, was then approached by other scholars as if it were real. In the genealogy Qazaq Şejiresinin Öleñmen Jazılğan Qısqaşa Mazmundama, this error was clearly highlighted in such a way that it stated the error should no longer be repeated, and the fact that the ancestor and the language of the Kazakhs was Turkish, and their religion was of Turkish and Tatar religion, i.e. Islam.

Boladı şın atamız bizdin Türik,

Negizsiz nege kerek qur ötirik.

Jönsiz bosqa adasuvdiñ jolı bar ma,

Däleldi ras sözdi köre turup.

Tilimiz - tüpki atamız Türik tili,

Dinimiz - Türik-Tatar tutqan dini (Babalar Sözi 81/ 56).
Our true ancestor is Turk,

Why the need for the unfounded rumour?

What's the point in being unfair, wrong?

After seeing the proven true word.

Our language and ancestor is Turkish,

Our religion is religion of Turk-Tatar.

\section{Division of Communities on Earth into Tribes and Phratries}

The handwritten genealogy called Düniyejüzindegi Halıqtarin Taypa, Ruvlarğa Bölinüvi was given to the Manuscripts Foundation in 1975 by Minat. It is impossible to read as the text is very archaic. It was transferred to the Cyrillic alphabet on an unknown date by someone whose name is unknown. Some pages were also lost during the transfer. It was originally published in volume 82 of Babalar Sözi (Babalar Sözi 82/ 363).

From the beginning to the Moñ ğoldardan Handiqtiñ ketip, Arkinaqun tavina qaşı barganı (Mongols lost the khanate and fled to Mount Ergenekon) section, this genealogy can be defined as the verse written form of Abu alGhazi Bahadur Khan's Shajara-i Taräkima.

In the second title of the genealogy, Moñğoldardan Handiqtiñ ketip, Arkinaqun tavina qaşıp bargani, the Ergenekon epic, which we know tells 
the time of Göktürks, is told as the Mongolian epic. According to the genealogy, the Mongols who lost their war with the Tatars took refuge in Mount Ergenekon, lived there for 400 years and left, and then fought the Tatars again and avenged ${ }^{16}$. Rövşen Alizade describes this as "müncer"17, that is, as a result of the indoctrination of the political authority of the Mongols, the source individuals showed the phenomena belonging to Turks such as Oghuznāma and Ergenekon as Mongols (29).

In the continuation of the genealogy, name taking of the Mongolian and Turkish phratries inspired by the Oghuznāmas and the division of the Kazakhs into zhuzes were explained. By saying Qazaqtıñ arğı atası Türikten erur, Yapistan bolğanina ärkim sener (First ancestor of the Kazakhs comes from the Turk, everyone believes that he is Yafes) (Babalar Sözi 82/ 296), the emphasis on Turkishness was made before moving onto telling of the division to the zhuzes.

\section{Conclusion}

The Kazakh genealogy remained in the outlines of the works of Jämi altawārikh and Shajara-i Taräkima. Except for genealogy written on order, where the descendants of Kazakhs were linked to the Arabs, and only the Kazakh phratries were told, the Kazakhs have included themselves to the ancestors in these two basic sources. The genealogies examined point out that Kazakhs are derived from the Turkish common ancestor and history confirms that they are descended from the same bloodline, and of course there are reasons as to why Kazakhs and Turks are referred as different nations. Seeing of this situation in other Turkish communities that have been subjected to Russian invasion, indicates the adherence to the policies that Russians have applied to Turkish phratries under their dominance.

It was seen that Turkishness consciousness existed in Kazakh genealogy which took an epic appearance in the state of verse. So much so that these genealogies are critical in order to gather Turkish people who are fragmented by many factors such as the change of geography, differentiation of historical flow, founding of different states, being referred with different names, political interventions, etc. in a common ancestor, i.e. under the identity of Turkish. 


\section{Notes}

1 Emir Timur's lineage was unified with Genghis Khan through his ancestor Tumanay Khan on the one hand, and his descent was taken back to Ali b. Abi Tâlib on the other, in the genaologies created by his successors (Yüksel 22, 44).

2 Seven ancestors are named as "äke, ata, äz ata, father, tektin, torkin, tuqiya" (Arğınbayev et al 6).

3 In Shajara-i Taräkima, the sons of Turk are "Tütek, Cigil, Barschak and Amlak" (Ebülgazi Bahadır Han 24). In Mejmüa al-tawärīkh, Prophet Noah has three sons: Ham, Sam and Yafes, and Jafes has three sons, Karahan, Azarhan and Küçihan (Çeribaş, Mecmûüt'-Tevârîh 57).

4 In Rashīd al-Dīn's Jāmi al-tawārìkh, Mongol Khan is referred to as "Dhîb Yavqu Khan" and his sons as "Qara Khan, Or-Han, Kur-Khan and KüzKhan" (Togan 17). In Shajere-i Terakime Mongol Khan is mentioned as the grandfather and Karahan as the father of Oghuz. Karahan's brothers are Kur Khan, Kır Khan and Or Khan (Ebülgazi Bahadır Han 25). Unlike Reşideddin and Abu Ghazi Bahadir Khan's depictions, in Mejmüa al-tawärīkh, Mongol Khan is shown as the only son of Oghuz Khan (Çeribaş, Mecmû̉üt-Tevârîh 57).

5 In Shajara-i Tarākima (Ebülgazi Bahadır Han 45) mentioned as Igdir, Büğdüz, Ava and Kınık but in Jämi al-tawārīkh as Yigdir, Büğdüz, Yıva, Kınıq (Togan 51-52).

6 Kine, Köne, Turpaqlı, Kereyli, Soltanlı, Oqlı, Kökli, Sojlı, Arasanlı, Yorıtşı, Toreş, Qomı, Sorq1, Qorçuq, Qaraçıq, Suraçık, Qazğurt, Tiyken, Lale, Mart, Suvi, Qırgız, Sayit Qatarlılar (Babalar Sözi V: 32 13). These 24 names are named as 23 people as Kene, Köne, Turbatlı, Gireyli, Sultanlı, Oklı, Kökli, Suçlı, Horasanlı, Yurtçı, Çamçı, Torumçı, Kumı, Sorkı, Kurçık, Suraçık, Karaçık, Kazgurt, Kırgız, Tigin, Lala, Mürdeşuy, Sayır in Shajara-i Taräkima. It is said that it was not known which son or sons of Oghuz Khan were from his second wives (Ebülgazi Bahadır Han 45).

7 In Kazakh and Kyrgyz genealogy, "etymological views" of naming tribes continue to exist as a tradition. It is worth noting that these etymological views are not only in genealogy, but also in legends and heroic epics. The etymological analysis of the name Kyrgyz in Mejmüa al-tawärīkh was performed and also in the Kyrgyz Manas Epic following lines can be seen regarding the name Kyrgyz: "Kirdagı Uguz baldarı (Oghuz sons in the steppe), Kır Uguz dep atağ1 (fame appeared as Kır Oghuz (Kyrgyz). Kırgız çıııp kır cakka (Kyrgyz come out to the steppe), Kır Uguz dep kalıptır (Kır Oghuz remained as his named) (Çeribaş, Manas Destaninnn 225-226). Also, see Timurlan Omarov (2008). 
“Turk Tribes according to Kyrgyz Genealogies”. Ankara University Institute of Social Sciences, Department of History (General Turkish History). Master's Thesis, p. 14-15.

8 The phratries that play an important role in shaping the social structure of the Kazakhs (Kalkan 224).

9 As a tradition in classical genealogy works in the region (such as Shajara-i Tarākima and Mejmü'a al-tawārīkh), the works begin with "purpose of statement, praising of god and appeal to god.

10 It is not understood what phratry this was. In genealogy it is stated that this phratry found a state in 1100 but it disappeared in the 12th century. We predict that it may be Khorezmshahs who established and destroyed a state in the given dates.

11 Sozaks are considered as the ancestors of Karapalpak Turks. https://abai.kz/ post/43733 (Access date: 16.02.2020).

12 Ergenekon epic and its name are also seen in Mejmü'a al-tawärïkh. In the work, it is based on a war between the sons of Oghuz and the Iranians, whence the Oghuz sought refuge to a mountain called Akanatun/ Ergenetun, where they propagated and continued their lives there until the time of the Prophet Muhammad (Çeribaş, Mecmûü̈t-Tevârîh 58).

13 Türiktiñ Ctambold meñgergeni, qasırdiñ on ekinşi orta kezi (Babalar Sözi V: 81 49). (Turk ruled Istanbul, the middle of the twelfth century) the date that the Turks took Istanbul was given incorrectly.

14 The legendary ancestor of the Kazakh Turks.

15 Essentially, this is not just a mockery. During the Tsarist Russia, in order to Russify and Christianize the Kazakhs, Nikolay Ilminskiy made suggestion to the Russian Government that it would be easier to assimilate the Kazakhs removed from Islam. Ilminsky's views were deemed appropriate and, both during the Tsarist and Soviet Russia times, practices to remove the Kazakhs from the religion of Islam were implemented as a state policy by missionaries to the Kazakh by continuous suggestion that they were shamans or heathens. Thus, the influence of Islam religion, which was the most important element that held Turkestan Turkishness together, was aimed to be broken (Yıldırım 300).

16 Bahaeddin Ögel reports that the Ergenekon epic was completely Mongolified in the Hamadanīs Jāmi al-tawārìkh, which is the most important source of the epic. He also says that Rashīd al-Dīn considers the Mongols as a separate phratry of the Turks (Ögel 60-61).

17 Carry away (Türkçe Sözlük 1728). 


\section{References}

Alizade, Rövşen. "Moğol-Türkmen Siyasi Karşıtlığı Bağlamında Oğuznameler ve Ergenekon Destanı.” Aydın Türklük Bilgisi Dergisi, no. 2, 2016, ss. 13-31.

Alpısbesulı, Maqsat. Qazaq Şejiresi: Tarihnamalıq-Derektanuvlıq Zerttev. BG-Print, 2013.

Arğınbayev, H. Et al. Qazaq Şejiresi Haqında. Atamura Baspası, 2000.

Arvas, Abdulselam. "Kırgız Şecereleri Üzerine Bir Değerlendirme." Karatekin Edebiyat Fakültesi Dergisi, vol. 4, no. 2, 1996, ss. 103-115.

Bozkurt, Nebi. "Şecere.” İslâm Ansiklopedisi, C. 38, Türkiye Diyanet Vakfı Yayınları, 2010.

Çeribaş, Mehmet. "Manas Destanı'nın Sagımbay Orozbakov Varyantında Aidiyet Duygusu ve Türk Kimliği." Türk Dünyası Araştırmaları, no. 196, 2012, ss. 201-228.

Çeribaş, Mehmet. "Kırgız Şecerecilik Geleneği ve Bu Gelenekte Türk Boyları Meselesi ve Oğuz Kağan.” Türk Kültürü Araştırmaları Dergisi, vol. 5, no. 1, 2012, ss. 61-78.

Çeribaş, Mehmet. Mecmûü't-Tevârîh-Türklerin Soyağacı ve Manas Destaninın Taribi Kaynă̆ı. Kesit Yay, 2019.

Ebülgazi Bahadır Han. Şecere-i Terakime. Haz. Muharrem Ergin, Tercüman 1001 Eser Yayınları, 1974.

İlliyev, Murat. Türk Tarihinde Şecere Geleneği: Türkmen Şecereleri Örnĕgi. Doktora Tezi. Ankara Üniversitesi, 2010.

Kalkan, Mustafa. Kirgızlar ve Kazaklar. Selenge Yay, 2006.

Karasoy, Yakup, ve Mustafa Toker. Türklerde Şecere Geleneği ve Anonim Şibanînâme. Tablet Kitabevi, 2005.

Kayabaşı, Onur Alp. Destan ve Hükümdar, Türk Destanlarında Devlet ve Yönetim. Konya: Kömen Yay, 2016.

Kesici, Kayyum. Dün Bugün ve Hedefteki Kazakistan. IQ Kültür Sanat Yayınları, 2003.

Köpeyulı, M. J. Qazaq Şejiresi. Altın Kitap, 2007.

Mıñjan, Nığmet. Qazaqtıñ Qısqaşa Tarihı. Jalın Baspası, 1994.

Omarov, Timurlan. Kırgız Şecerelerine Göre Türk Boyları. Yüksek Lisans Tezi. Ankara Üniversitesi, 2008.

Ögel, Bahaeddin. Türk Mitolojisi. C. 1. Türk Tarih Kurumu Yayınları, 1993.

Sıpatayulu, Samat. "Turan eli-Qıran Eli.” Alaş Aynası, no. 5, 26.03.2010.

"Şejirelik Dastandar.” Babalar Sözi, no. 32, 2006.

“Şejirelik Jır, Añızdar.” Babalar Sözi, no. 81, 2012.

“Şejirelik Jır, Añızdar.” Babalar Sözi, no. 82, 2012. 
Temur, Nezir. “Sözlü Tarih ve Destan Bağlamında Mecmuatu't-Tavorih.” Türkbilig, no. 35, 2018, ss. 223-231.

Togan, Zeki Velidî. Oğuz Destanı: Reşîdeddin Oğuznamesi Tercüme ve Tahlili. Enderun Yayınları, 1982.

Türk Dünyası Edebiyat Kavramları ve Terimleri Ansiklopedik Sözlüğü. C. 5. Atatürk Kültür Merkezi Yayınları, 2006.

Türkçe Sözlük. TDK Yayınları, 2011.

Yeşil, Yılmaz. Türk Dünyasında Geçiş Dönemi Ritüelleri. Grafiker Yayınları, 2014.

Yeşil, Yılmaz. Türk Sözlü Anlatılarında Şekil Değiştirme. Kalem Kitap Yayınları, 2015.

Yeşildal, Ünsal Yılmaz. "Atalar Kültüne Dair İnanmaların Türklerin Ad Verme İnanç ve Gelenekleri Üzerindeki Tesiri.” Milli Folklor, no. 119, 2018, ss. 48-59.

Yıldırım, Seyfullah. "Bağımsızlık Sonrası Dönemde Kazak Kültürünün Korunmasına Yönelik Yapılan Çalışmalar.” Türk Cumhuriyetlerinde Bağımsızlık ve Devlet İnşa Süreci, ed. Mehmet Akif Kireçci, Ahmet Yesevi Üniversitesi Yayınları, 2018, ss. 293-308.

Yüksel, Musa Şamil. Timurlularda Din-Devlet İlişkisi. Türk Tarih Kurumu Yayınları, 2009.

Qazaq Ädebi Tiliniñ Sözdigi. C. 15. Dävir Baspası, 2011.

Qudayberdiulı, Ş. Türik, Qırgız-Qazaq Häm Hanlar Şejiresi. C. 28. Altın Kitap, 2007.

https://abai.kz/post/43733 (Erişim Tarihi: 14.12.2019). 


\section{Kazak Şecerelerinde Türk Algısı ve Ortak Ata*}

\section{Seyfullah Yıldınm** Mehmet Topay ${ }^{* * *}$}

$0 ̈ z$

Şecere, bir kişinin veya ailenin en uzak atasından başlayarak kendisine kadar gelen bütün fertlerini gösteren çizelge, soyağacı olarak tanımlanmaktadır. Kazak Türkçesinde "Şejire" (шежipe) olarak adlandırılan, Kazak sözlü edebiyatında önemli bir tür olan şecereler, sözlü gelenekte uzun yıllar jırav, akın gibi sözlü icra geleneğinin temsilcileri tarafından söylenerek günümüze ulaştırılmış ve bugün büyük oranda yazıya geçirilmişlerdir. Şecereler, her ne kadar sözlü olarak nesilden nesle aktarılırken büyük değişikliklere uğramış olsa da sözlü tarihin en önemli kaynaklarından biridir. Öyle ki Türk tarihi açısından büyük önem arz eden Oğuz Kağan başta olmak üzere birçok tarihi kişiliği ve olayları "Oğuzname" olarak adlandırılan şecerelerden öğrenmekteyiz. Kazak şecerelerinin de özelikle Reşîdeddin’in Cami’ü’t-Tevarih ve Ebülgazi Bahadır Han'ın Şecere-i Terakime adlı eserlerinden etkilendiği görülmektedir. Bu makalede Kazak Türklerinin şecerecilik geleneği üzerinde durulacak ve köken olarak Kazakları Türk kökenine bağlayan şecerelerdeki Türk algısı ve Türkler arasında ortak kabul edilen şahsiyetler ortaya konulmaya çalı̧ıllacaktır.

\section{Anahtar Kelimeler}

Kazak Türkleri, Kazaklarda Şecerecilik Geleneği, Türk Algısı, Ortak Ata, Oğuz Kağan.

\footnotetext{
" Geliş Tarihi: 07 Aralık 2020 - Kabul Tarihi: 26 Nisan 2021

Bu makaleyi şu şekilde kaynak gösterebilirsiniz:

Yıldırım, Seyfullah, ve Mehmet Topay. "Perception of Turks and Common Ancestor in Kazakh Genealogy." bilig, no. 100, 2022, ss. 37-58.

"Ass. Prof. Dr., Ankara Yildirim Beyazit University, Faculty of Humanities and Social Sciences, Department of Turkish Language and Literature - Ankara / Turkey

ORCID ID: 0000-0002-4345-6524

s.yildirim@ybu.edu.tr; seyfiyildirim@gmail.com

"*tecturer, Ankara Yildirim Beyazit University, Rectorate / DILMER - Ankara / Turkey

ORCID ID: 0000-0003-4191-7838

mtopay@ybu.edu.tr
} 


\section{Восприятие тюрков и Общий предок в казахской генеалогии}

\section{Сейфуллах Йылдырым** Мехмет Топай ${ }^{\text {** }}$}

\section{Аннотация}

Шеджере представляет собой схему, которая показывает всех предков отдельной личности или всех членов семьи, фактически это родословное древо. Родословия, которые на казахском тюркском языке называются шежіре, являются важным жанром в казахской устной литературе, на протяжении многих лет они исполняются представителями устной традиции, такими как джирав и акын, и в наши дни большое число их записано. Шеджере являются одним из важнейших источников устной истории, хотя, передаваясь устно из поколения в поколение, она могла претерпеть большие изменения. Например, из шеджере под названием «Огузнаме» мы узнаем о многих исторических личностях, особенно Огуз Кагане, и событиях, которые имеют большое значение с точки зрения тюркской истории. Видно, что на казахские генеалогии особенно повлияли «Джами ат-таварих» Рашид ад-Дина Хамадани и «Родословная туркмен» Абулгази Багадур-хана. В данной статье делается акцент на генеалогической традиции казахов и предпринимается попытка раскрыть восприятие тюрков в шеджере, в которых казахи связываются с их тюркскими предками, а также выявляются общие личности тюркской истории.

\section{Ключевые слова}

Казахские тюрки, традиция шеджере у казахов, восприятие тюрков, общий предок, Огуз-хан.

\footnotetext{
* Поступило в редакцию: 07 декабря 2020 г. - Принято в номер: 26 апреля 2021 г. Ссылка на статью:

Yıldırım, Seyfullah, and Mehmet Topay. "Perception of Turks and Common Ancestor in Kazakh Genealogy." bilig, no. 100, 2022, pp. 37-58.

** Доц., д-р, Университет Йылдырым Беязит, Анкара, факультет гуманитарных и социальных наук, кафедра турецкого языка и литературы - Анкара / Турция ORCID ID: 0000-0002-4345-6524 s.yildirim@ybu.edu.tr; seyfiyildirim@gmail.com

*** Преп., Университет Йылдырым Беязит, Анкара, ректорат / ДИЛМЕР - Анкара / Турция ORCID ID: 0000-0003-4191-7838 mtopay@ybu.edu.tr
} 